\title{
Sağlık Turizmi İşletmelerinde Hizmet Telafi Stratejilerinin Olumlu Ağızdan Ağıza İletişim ve Tekrar Satın Alma Niyetine Etkisi*
}

\author{
The Effect of Service Recovery Strategies in Health Tourism Enterprises on \\ Positive Word-of-Mounth Communication and Repurchase Intention
}

Makale Türü: Araştırma Makalesi Article Type: Research Article

Makale Geliş

Tarihi/Received:06/11/2021

Makale Kabul

Tarihi/Accepted:21/11/2021

Anahtar Kelimeler: Sağlık turizmi, hizmet telafi stratejileri, ağıdan ağıza iletişim, tekrar satın alma niyeti

Keywords: Health tourism, service recovery strategies, word-of-mouth communication, repurchase intentions

a(Sorumlu yazar) Yüksek Lisans öğrencisi, Sivas Cumhuriyet Üniversitesi, cansellbas60@gmail.com (iD) 0000-0002-4910-9985

bDoç. Dr., Sivas Cumhuriyet Üniversitesi, sukrankaraca@gmail.com (D) 0000-0002-0268-1810

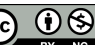
Commons Atıf-GayriTicari 4.0 (CC BY-NC 4.0) kapsamında açık erişimli bir makaledir.
Öz

Amaç: Sağlık turizmi hizmeti veren işletmelerde hizmet telafi stratejilerinin olumlu ağızdan ağıza iletişim ve tekrar satın alma niyetine etkisinin incelenmesidir. Gereç ve Yöntem: Araştırma kapsamında 360 kişiden çevrimiçi anket tekniği ile veriler elde edilmiştir. Veriler 1 Mart - 8 Ağustos 2021 tarihleri arasında toplanmıştır. Verilere PLS-SEM ile Doğrulayıcı Faktör Analizi ve Yol Analizi uygulanmıştır. Bulgular ve Sonuç: Çalışmada kullanılan ölçeğin model uyum değerlerini ve ayrışma geçerliliğini sağladığı ve güvenilir bir ölçek olduğu görülmüştür. Yapılan yol analizi sonucunda; hizmet telafi stratejisinin dakiklik boyutunun tekrar satın alma niyeti üzerinde, telafi boyutunun ise hem olumlu ağızdan ağıza iletişim ve hem de tekrar satın alma niyeti üzerinde etkisinin olduğu tespit edilmiştir. Fornell-Larcker kriteri incelendiğinde ise, hizmet telafi stratejilerinin tüm boyutları ile olumlu ağızdan ağıza iletişim ve tekrar satın alma niyeti arasında anlamlı ve pozitif bir ilişki olduğu tespit edilmiştir.

\begin{abstract}
Aim: The aim of this study is to examine the effect of service recovery strategies on positive word of mouth communication and repurchase intention in companies providing health tourism services. Materials and Methods: Within the scope of the research, data were obtained from 360 people with the online survey technique. Data were collected from March 1 to August 8, 2021. Confirmatory Factor Analysis and Path Analysis were applied to the data with PLS-SEM. Findings and Result: It was seen that the scale used in the study provided model fit values and discriminant validity and was a reliable scale. As a result of the road analysis; it has been determined that the punctuality dimension of the service recovery strategy has an effect on the repurchase intention, and the compensation dimension has an effect on both positive word of mouth communication and repurchase intention. When the Fornell-Larcker criterion is examined, it has been determined that there is a significant and positive relationship between all dimensions of service recovery strategies, positive word of mouth communication and repurchase intention.
\end{abstract}

*Bu çalışma Cansel BAŞ’ın yüksek lisans tezinden üretilmiştir.

Bu Yayına Atıfta Bulunmak İçin/Cite as:

Baş, C. ve Karaca, Ş. (2021). Sağlık turizmi işletmelerinde hizmet telafi stratejilerinin olumlu ağıdan ağıza iletişim ve tekrar satın alma niyetine etkisi, Güncel Pazarlama Yaklaşımları ve Araştırmaları Dergisi, 2(2), 110-122. https://doi.org/10.54439/gupayad.1020082 


\section{Giriş}

İnsanların ikamet ettikleri yerden başka yerlere herhangi bir sebeple sağlık hizmeti satın almak için yaptıkları planlı seyahatler sağlık turizmi olarak tanımlanmaktadır (Tengilimoğlu ve Işık 2013, s.29). Sağlık turizmi çok sayıda insana yurtdışında kolay erişilebilir ve uygun fiyatlı sağlık hizmetleri imkânı sunmaktadır (Ridderstaat ve Singh 2020, s.38). Bu nedenle insanların sağlık hizmeti alma isteği artmakta ve sağlık turizminin gelişmesiyle birlikte rekabet ortamı oluşmaktadır. Artan rekabet koşulları nedeniyle sağlik turizmi hizmeti veren işletmeler, müşteri memnuniyeti öneminin vurgulandığı, nitelikli ve etkili bir hizmeti amaçlamaktadır (Denizli, 2020, s.1).

Sağlık turizm işletmelerinde memnuniyetsizliği meydana getiren temel sebep aksaklıkların mevcudiyetidir. Hizmet sunumu esnasında meydana gelen aksaklıklar, şikâyetlere yol açmakta ve şikâyetlerin giderilmemesi durumunda işletmeler için olumsuz sonuçlar ortaya çıkabilmektedir (Um ve Lau, 2018, s. 8). Aldığ1 hizmetler sonucu memnun olmayan müşteri diğer işletmelere geçiş yapmakta ve bu durum işletmeler için zaman, maddiyat ve güç kaybı gibi olumsuzluklara yol açmaktadır. Dolayısıyla, bu unsurlar işletmenin imajına da zarar verebilmektedir.

Hizmet sunumunda herhangi bir aksaklık ile karşılaşan bireyler, çevresinde bulunan ve hizmet satın alma talebi olan bireylere daha önce hizmet satın aldığı işletme hakkında olumsuz söylemlerde bulunarak negatif iletişim sürecine geçebilmektedirler (Demirel, 2019, s. 1). Bu yüzden şikâyet yönetimi turizm ve sağlık turizmi işletmelerinde giderek daha önemli hale gelmiştir. Ancak şikâyet eden kişilerin işletmelerin şikayetlere yönelik tepkilerini nasıl değerlendirdiği ve ağızdan ağıza iletişim ile tekrar satın alma niyetleri söz konusu olduğunda bu değerlendirmelerin gelecekteki davranışlarını nasıl etkilediği hakkında çok az şey bilinmektedir (Davidow, 2000, s. 473). Bu bağlamda bu çalışma, sağllk turizmi işletmelerine şikâyette bulunan kişilerin şikâyetlerinin işletmeler tarafından nasıl telafi edildiğini ve bu hizmet telafi stratejilerinin olumlu ağızdan ağıza iletişime ve tekrar satın alma niyetine etkisini incelemek amaciyla yapılmıştır. Yerli ve yabancı literatür incelendiğinde hizmet telafi stratejilerinin sağlık sektöründe incelendiği çalışmalar (Okyere ve Kumadey 2015; Krishna vd., 2011; Cengiz vd., 2015; Mete, 2021) olmasına rağmen sağlık turizmi işletmeleri kapsamında incelendiği bir çalışmaya rastlanılamamış olması çalışmanın özgünlügü ile literatüre ve topluma sağlayacağ 1 katkı açısından önemlidir.

\section{Kavramsal Çerçeve}

Hizmet telafisi, hizmet hatalarını iyileştirerek müşteri tatminini sağlamak ve işletmelerin hizmet kalitesini müşteri algıları doğrultusunda oluşturmak amacıyla geliştirilen bir stratejidir (Brown vd., 1996, s. 32). Başka bir ifadeyle hizmet telafisi, müşterinin hizmet hatası ile ilgili şikâyetleri işletmeye ulaştı̆̆ında, işletmenin düzeltme şansının arttığ tüm faaliyetlerdir (Grönroos, 1990, s. 7). Aslında en iyi strateji sunulan hizmetlerde standardı sağlayarak hataların önüne geçmektir. Ancak hizmetler soyut olduğu için bu durum çok da mümkün değildir. Bu nedenle, hizmet başarısızlıklarına etkili bir şekilde yanıt vererek kaliteli hizmet sunan işletmeler, kârlı müşterileri elde tutarak çok daha iyi bir konumda olmaktadırlar (Michel ve Meuter, 2008, s. 442). Hizmet telafi stratejilerinin en önemli sonuçlarından biri müşteri bağlılığının kârlılığı beraberinde getirmesidir. Aynı zamanda hizmet telafisi müşteri tatmini, güven ve sadakatin temel belirleyicisi olmakla beraber müşteriyle iletişimin zamanla gelişmesine de katkı sağlamaktadır (Yağcı ve Doğrul, 2015, s. 8).

Hizmet telafi stratejileri sinıflandırmalarıyla ilgili yapılan değerlendirmeler sonucu literatürde en çok kabul gören sınıflandırma Davidow (1998; 2000; 2003)'a aittir ve mevcut çalışma Davidow (2003) tarafından yapılan hizmet telafi siniflandırılması temelinde gerçekleştirilmiştir. Davidow (1998; 2000; 2003) çalışmalarında hizmet telafi stratejilerini altı başlıkta toplamıştır. Bu hizmet telafi stratejileri; dakiklik, kolaylaştırma, özür, güvenirlik, nezaket ve tazminattır. Müşteriler tarafından 
işletmeye ulaştırılan şikayetlere ne kadar hızlı yanit verildiği dakiklik (Davidow, 2000, s. 475), bir işletmenin müşteri şikâyetlerini desteklemek için uyguladığı politikalar, prosedürler ve araçlar kolaylaştırma (Davidow, 2000, s. 475), müşteri de işletmenin hata yaptığını kabul ettiği ve duyarlı davrandığı hissi oluşturan ve tek başına yeterli olmayan strateji özür (Cengiz vd., 2015 , s. 90), hataların iletişim yoluyla telafi edilmesi ve müşteriye işletmenin problemin farkında olduğunun hissettirilmesi güvenirlik (Akdu, 2019, s. 628), müşterinin kuruluştan veya temsilcilerinden aldığı özen ve ilgi nezaket (Davidow, 2003, s. 243), müşterinin şikâyete yanit olarak kuruluştan aldığ1 faydalar veya yanitlar (Davidow, 2003, s. 232) ise tazminat stratejisini ifade etmektedir.

Sağllk hizmeti veren kuruluşlarda yaşanan hizmet hatalarının müşteriler tarafından bildirebileceği sistemler oluşturulduğu (Hayden vd., 2010, s. 310) takdirde işletmeler verdikleri hizmetlerdeki başarısızlıkların nedenlerini belirleyerek uygun hizmet telafi stratejileri oluşturabilirler. Bu sayede verilen hizmetlerin kalitesi artarak sağlık turistlerinin memnuniyetleri artmaktadır (Berman, 2005, s. 129; Um ve Kim, 2018, s. 5). Corbin vd. (2001, s. 6) tarafından yapılan bir çalışmada, sağlık hizmeti veren işletmelerde bireylerin güven ve sadakat duygularının geliştirilebilmesi için sunulan telafilerin hızlı ve adil şekilde olması gerektiği belirtilmiştir. $\mathrm{Bu}$ durumun müşterilerin hatalar hakkındaki olumsuz iletişim oranını azaltabileceği savunulmaktadır. Wirtz ve Mattila (2003, s. 161); tazminat, telafi hızı ve özür stratejisinin müşteri memnuniyeti sağlamadaki rolünü önem derecelerine göre karşılaştırdıkları çalışmalarında; hızlı telafi ve özrün beraber sunulduğunda etki derecesinin fazla olduğu, tazminat stratejisine gerek duyulmadığı ve telafi etme çabasının gecikmesi durumunda özrün çok etkili olmadığını ifade etmişlerdir. Türkoğlu (2007, s. 74) tarafından konaklama işletmelerinde yapılan çalışmada, hizmet telafi süresinin azaltılmasının müşteri tatminini olumlu etkileyeceği belirtilmiştir. Bozkaya (2012, s. 107) tarafından bankacılık sektöründe yapılan çalışmada da, hizmet telafi stratejilerinin etkin yapılmasında müşterilerin memnun olacağı ve aynı bankada kalacağı ifade edilmiştir.

Ağızdan ağıza iletişim, günlük yaşamın büyük bir parçasıdır. İnsanlar genellikle haberleri, fikirleri ve bilgileri arkadaşları, aile üyeleri ve diğer sosyal çevreleriyle paylaşırlar. $\mathrm{Bu}$ paylaşımlar tüketici davranışı üzerinde önemli bir etkiye sahiptir (Chen ve Berger, 2016, s. 86). Sağlık hizmetlerinde, hizmet satın alınırken bireyler sosyal medya, referans grupları, yakın çevre gibi çeşitli iletişim ağlarına yönelmektedir (Aydemir vd., 2020, s. 311). Ferguson vd. (2006) tarafından yapılan bir çalışmada sağlık hizmetlerinden ilk kez yararlanan hastaların \%34'ünün sağlık personelinin, \%13'ünün arkadaş ve akrabasının, $\% 49$ 'unun ise daha önceden hizmet alan kişilerin önerileriyle sağlık hizmeti veren işletmelere başvurdukları belirtilmiştir (Akt: Aydemir vd., 2020, s. 315). Malezya'da yapılan bir çalışmada da ağızdan ağıza iletişimin önemi vurgulanmış, Malezya'ya gelen medikal turistlerin büyük bir çoğunluğunun arkadaş $(\% 44,5)$, aile üyeleri $(\% 37,7)$ ve doktor $(\% 24,5)$ tavsiyesi ile geldikleri ifade edilmiştir (Yeoh vd., 2013, s. 199). Çanakgöz (2008, s. 135) tarafından bankacılık sektöründe yapılan çalışmada, hizmet hatasıyla ilgili şikâyette bulunan katılımcıların daha yüksek düzeyde ağızdan ağıza iletişime geçtiği tespit edilmiştir. Kılınç (2020, s. 71), sağlık turizminde elektronik ağızdan ağıza iletişimin seyahat niyeti üzerinde etkisini incelediği çalışmasında; ağızdan ağıza pazarlamanın seyahat niyeti üzerinde pozitif ve anlamlı etkisinin olduğu sonucuna ulaşmıştır. Bu bilgiler 1şığında şu hipotez oluşturulabilir:

H1:Hizmet telafi stratejilerinin olumlu ağızdan ağıza iletişim üzerinde pozitif bir etkisi vardır.

Hizmet telafisi, şikâyet eden kişinin hizmeti tekrar satın almaya devam etmesi ve deneyimi hakkında olumlu ağızdan ağıza iletişim faaliyetine girmesi durumunda başarılı olmaktadır (Davidow, 2000, s. 474). Kim vd. (2010) hizmet telafisinin olumlu sonuçlarını; müşterinin tekrar satın alma niyetinin olması, çevresine olumlu önerilerde bulunması ve 
işletmeye yeniden gelmesi olarak ifade etmiştir. Conlon ve Murray (1996) müşterilerin şikayetlerine yanıt hızının tekrar satın alma niyetleriyle pozitif bir ilişkisi olduğunu belirtmişlerdir. Dolinsky (1995, s.42), sağlık hizmeti veren işletmelerde tüketicilerin şikâyetleri ilk aşamada olumlu bir şekilde çözülürse memnuniyet düzeylerinin ve tekrar satın alma ihtimallerinin önemli ölçüde arttığını ifade etmişlerdir. Ratnasari vd. (2019) ise, sağlık hizmeti kalitesinin sağllk hizmetini tavsiye niyeti ve sağlık hizmetini tekrar satın alma niyeti üzerinde etkili olduğunu tespit etmişlerdir. Wongsawat ve Deebhijarn (2020, s. 112) tarafından medikal turizm alanında yapılan bir çalışmada ise, sunulan hizmetlere yönelik kalite algisının müşteri memnuniyeti oluşturduğu ve aynı zamanda medikal turistlerin tekrar satın alma niyetini de etkilediği sonucuna ulaşılmıştır. $\mathrm{Bu}$ bilgiler doğrultusunda şu hipotez oluşturulabilir:

$\mathrm{H}_{2}$ :Hizmet telafi stratejilerinin tekrar satın alma niyeti üzerinde pozitif bir etkisi vardır.

\section{Yöntem}

$\mathrm{Bu}$ çalışmanın amacı sağlık turizmi işletmelerinde hizmet telafi stratejilerinin olumlu ağızdan ağıza iletişim ve tekrar satın alma niyetine etkisinin incelenmesidir. Çalışma kapsamında oluşturulan anket formu 4 bölüm ve 48 ifadeden oluşmaktadır. Anket formunun ilk kısmında Davidow (2000) tarafından geliştirilmiş ve Akdu (2019) tarafından güvenilirlik ve geçerliliği test edilmiş olan "Hizmet Telafi Stratejisi Ölçeği", ikinci kısımda Goyette (2010) tarafından geliştirilen Türker (2013) tarafından Türkçeye uyarlanan "Ağızdan Ağıza İletişim Ölçeği", üçüncü kısımda Rauyruen vd. (2009) tarafından geliştirilen Özbek vd. (2012) ile Çakırkaya ve Karaboğa (2019) tarafından Türkçeye uyarlanan "Tekrar Satın Alma Niyeti Ölçeği" kullanılmıştır. Ölçekler 5'li Likert tipinde (1)Kesinlikle Katılmiyorum, (2)Katılmiyorum (3) $\mathrm{Ne}$ Katıliyorum Ne Katılmıyorum (4)Katılıyorum, (5)Kesinlikle Katılyyorum şeklinde hazırlanmıştır. Anket formunun son kısmında katılımcıların demografik özelliklerini belirlemeye yönelik sorular ve sağlık turizmi işletmelerine yapılan şikâyetler ile ilgili çoktan seçmeli sorular yer almaktadır.

Araştırmanın evrenini Türkiye'de sağlık turizmi işletmelerinde şikâyette bulunmuş kişiler oluşturmaktadır. Araştırmanın örneklemini ise 18 yaşından büyük, sağlık turizm işletmelerine şikâyette bulunmuş ve Facebook, Instagram, Twitter ve Whatsapp gibi internet tabanlı uygulamaları kullanan kişiler oluşturmaktadır. Çevrimiçi anket tekniği ile 1 Mart-8 Ağustos 2021 tarihleri arasında 373 katılımcıya ulaşılmış, eksik ve yanlış olan 13 anket değerlendirmeye alınmamıştır. Analizler 360 anket üzerinden yapılmıştır.

\subsection{Araştırma Modeli ve Hipotezler}

$\mathrm{Bu}$ araştırmanın amacı hizmet telafi stratejilerinin (kolaylaştırma, dakiklik, özür, nezaket ve telafi) olumlu ağızdan ağıza iletişim ve tekrar satın alma niyeti üzerine etkisinin incelenmesidir. Bu kapsamda araştırma modeli 3 değişkenden oluşmaktadır. Bunlar; hizmet telafi stratejileri, olumlu ağızdan ağıza iletişim ve tekrar satın alma niyetidir. Hizmet telafi stratejileri ölçeği 6 boyuttan (Dakiklik, Kolaylaştırma, Özür, Güvenilirlik, Nezaket ve Telafi), olumlu ağızdan ağıza iletişim ölçeği tek boyuttan ve tekrar satın alma niyeti ölçeği de tek boyuttan oluşmaktadır.

Bu bilgiler ışığında araştırma modeli Şekil 1'de sunulmuştur. Araştırmanın modeli doğrultusunda oluşturulan hipotezler şu şekildedir:

$\mathrm{H}_{1}$ : Hizmet telafi stratejilerinin olumlu ağızdan ağıza iletişim üzerinde pozitif bir etkisi vardır.

$\mathrm{H}_{1 \mathrm{a}}$ Kolaylaştırma stratejisinin olumlu ağızdan ağıza iletişim üzerinde pozitif bir etkisi vardır.

Hib:Dakiklik stratejisinin olumlu ağızdan ağıza iletişim üzerinde pozitif bir etkisi vardır.

$H_{1 c:}$ Özür stratejisinin olumlu ağızdan ağıza iletişim üzerinde pozitif bir etkisi vardır.

H1d:Nezaket stratejisinin olumlu ağızdan ağıza iletişim üzerinde pozitif bir etkisi vardır. 
H1e: Telafi stratejisinin olumlu ağızdan ağıza iletişim üzerinde pozitif bir etkisi vardır.

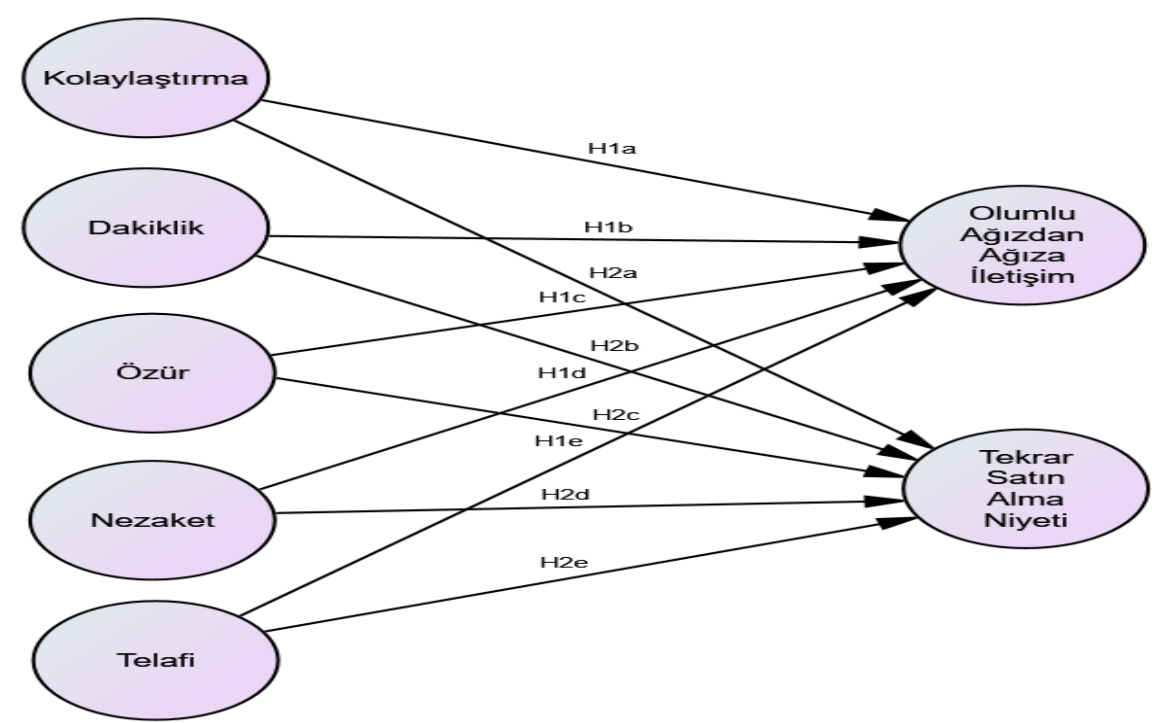

$\mathrm{H}_{2}$ : Hizmet telafi stratejilerinin tekrar satın alma niyeti üzerinde pozitif bir etkisi vardır.

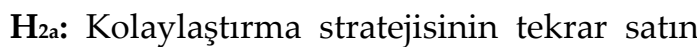
alma niyeti üzerinde pozitif bir etkisi vardır.

$\mathbf{H}_{2 b}$ : Dakiklik stratejisinin tekrar satın alma niyeti üzerinde pozitif bir etkisi vardır.

$\mathbf{H}_{2}$ : Özür stratejisinin tekrar satın alma niyeti üzerinde pozitif bir etkisi vardır.
$\mathbf{H}_{2 \mathrm{~d}}$ : Nezaket stratejisinin tekrar satın alma niyeti üzerinde pozitif bir etkisi vardır.

$\mathbf{H}_{2 \mathbf{2}}$ : Telafi stratejisinin tekrar satın alma niyeti üzerinde pozitif bir etkisi vardır.

\section{Analiz ve Bulgular}

Çalışma kapsamında elde edilen verilerin analizinde SPSS ve Smart PLS-SEM programları kullanılmıştır.

Tablo 1

Demografik Özellikler

\begin{tabular}{|c|c|c|c|c|c|}
\hline Cinsiyet & $\mathrm{f}$ & $\%$ & Medeni Durum & $\mathrm{f}$ & $\%$ \\
\hline Kadın & 172 & 47,8 & Evli & 163 & 45,3 \\
\hline Erkek & 188 & 52,2 & Bekar & 197 & 54,7 \\
\hline Toplam & 360 & 100 & Toplam & 360 & 100 \\
\hline Yaş & $\mathrm{f}$ & $\%$ & Eğitim & $\mathrm{f}$ & $\%$ \\
\hline $18-26$ & 126 & 35 & İlköğretim & 13 & 3,6 \\
\hline $27-35$ & 92 & 25,6 & Lise & 50 & 13,9 \\
\hline $36-44$ & 69 & 19,2 & Önlisans & 76 & 21,1 \\
\hline $45-53$ & 43 & 11,9 & Lisans & 163 & 45,3 \\
\hline 54 yaş ve üzeri & 30 & 8,3 & Lisansüstü & 58 & 16,1 \\
\hline Toplam & 360 & 100 & Toplam & 360 & 100 \\
\hline Meslek Dağılımı & $\mathrm{f}$ & $\%$ & Gelir & $\mathbf{f}$ & $\%$ \\
\hline Kamu Sektörü Çalışanı & 120 & 33,3 & 2500 TL ve altı & 105 & 29,2 \\
\hline Ev Hanımı & 20 & 5,6 & $2501-4000 \mathrm{TL}$ & 69 & 19,2 \\
\hline Özel Sektör Çalışanı & 76 & 21,1 & $4001-5500$ & 63 & 17,5 \\
\hline Serbest Meslek Çalışanı & 21 & 5,8 & $5501-7000 \mathrm{TL}$ & 59 & 16,4 \\
\hline Öğrenci & 72 & 20 & $7001-8500 \mathrm{TL}$ & 30 & 8,3 \\
\hline İşsiz & 25 & 6,9 & 8501 TL ve üzeri & 34 & 9,4 \\
\hline Diğer & 26 & 7,2 & & & \\
\hline Toplam & 360 & 100 & Toplam & 360 & 100 \\
\hline
\end{tabular}

Çalışmada ilk olarak ölçeklerin güvenirlilik ve geçerliliğine yönelik analizler yapılmıştır.
Daha sonra PLS-SEM yöntemi ile doğrulayıcı faktör analizi ve yol analizi yapılarak hizmet 
telafi stratejilerinin olumlu ağızdan ağıza iletişim ve tekrar satın alma niyeti üzerindeki etkisi ortaya konulmuştur.

Katılımcıların demografik özelliklerine yönelik bulgular Tablo 1'de gösterilmiştir. Araştırmaya katılanların \%47,8'inin kadın, $\% 52,2$ 'sinin erkek; \%45,3'ünün evli, \%54,7'sinin bekâr; \%35'inin 18-26 yaş aralığında; $\% 45,3$ 'ünün lisans mezunu ve \%33,3'ünün kamu çalışanı olduğu görülmektedir.

Şikâyetlere yönelik sorulara ilişkin bilgiler Tablo 2'de sunulmuştur. Tablo 2'ye göre; araştırmaya katılan kişilerin en yüksek şikâyette Tablo 2

Şikâyetlere Yönelik Sorulara İlişkin Bilgiler

\begin{tabular}{|c|c|c|c|c|c|}
\hline $\begin{array}{l}\text { Şikâyette bulunulan sağlık turizmi } \\
\text { hizmeti veren işletme }\end{array}$ & f & $\%$ & $\begin{array}{l}\text { Şikâyetin hangi yolla sağlık hizmeti } \\
\text { veren işletmeye iletildiği }\end{array}$ & f & $\%$ \\
\hline Termal Turizm Hizmeti Sunan İşletme & 183 & 50,8 & Yüz yüze görüşme & 128 & 35,6 \\
\hline Medikal Turizm Hizmeti Sunan İşletme & 97 & 26,9 & Telefon/ Çağrı Merkezi & 106 & 29,4 \\
\hline Yaşlılara Yönelik Hizmet Sunan İşletme & 54 & 15 & Şikâyet Kutusu & 19 & 5,3 \\
\hline Engellilere Yönelik Hizmet Sunan İşletme & 26 & 7,2 & E mail & 31 & 8,6 \\
\hline Şikâyetin konusu & $\mathrm{f}$ & $\%$ & Şikâyet - Yorum Siteleri & 57 & 15,8 \\
\hline Fiyat-Reklam-Kampanya & 135 & 18 & Sosyal Medya (facebook, twitter vs.) & 17 & 4,7 \\
\hline Personel & 129 & 17,2 & Diğer & 2 & 0,6 \\
\hline Ulaşım & 63 & 8,4 & Kim için şikâyette bulunulduğu & $\mathbf{f}$ & $\%$ \\
\hline Web Hizmeti & 35 & 4,7 & Kendim & 144 & 40 \\
\hline Eğlence Hizmeti & 45 & 6 & Ailem & 130 & 36,1 \\
\hline Bekleme süresi & 91 & 12,1 & Akrabam & 50 & 13,9 \\
\hline Konaklama Hizmeti & 92 & 12,3 & Arkadaşım & 34 & 9,4 \\
\hline Ek hizmet & 44 & 5,9 & Diğer & 2 & 0,6 \\
\hline Ülkedeki Yasal ve Ahlaki Sorunlar & 23 & 3,1 & Şikâyetiniz çözüldü mü? & $\mathbf{f}$ & $\%$ \\
\hline $\begin{array}{l}\text { Sağlık Sigortasının Hizmetleri } \\
\text { Kapsamaması }\end{array}$ & 27 & 3,6 & Evet & 79 & 31,9 \\
\hline $\begin{array}{l}\text { Sağlık Kuruluşlarının Teknolojik } \\
\text { Ekipmanların Yetersizliği }\end{array}$ & 34 & 4,5 & Hayır & 154 & 42,8 \\
\hline Aracı Kurumlar & 19 & 2,5 & Kismen & 127 & 35,3 \\
\hline Diğer & 13 & 1,7 & & & \\
\hline
\end{tabular}

\subsection{Güvenilirlik ve Geçerlilik Analizleri}

Çalışmada Cronbach Alfa ile ölçekteki faktörlerin iç tutarlılı̆̆ 1 hesaplanmıştır. Cronbach Alfa değerleri; 0,00- 0,40 ise "Güvenilir Olmayan Ölçek", 0,40-0,60 ise "Düşük Güvenilir Ölçek", 0,60-0,80 ise "Güvenilir Ölçek", 0,80-1,00 ise "Yüksek Güvenilir Ölçek" olarak kabul edilmektedir (Kalaycı, 2010, s. 321). Çalışmada kullanılan ölçeklere ait faktörlerin güvenilirlik ve geçerlilik analizi sonuçları Tablo 3 'te gösterilmiştir. Tablo 3 çalışmanın geçerliliği için faktör yüklerini göstermektedir. Hizmet telafi stratejileri bulundukları sağlık turizmi işletmesinin \%50,8 ile termal turizm işletmeleri olduğu görülmektedir. En fazla şikâyet edilen konu \%18 ile fiyat-reklam-kampanya olurken ikinci sirada \%17,2 ile personelden kaynaklı şikâyetler gelmektedir. Araştırmaya katılan kişilerin \%40'1 kendisi için şikâyette bulunduğu ve \%35,6'sının şikâyetlerini yüz yüze görüşerek, \%29,4'ünün ise telefon/ çağrı merkezi yoluyla ilettiği görülmektedir. Son olarak şikâyette bulunan kişilerin \%31,9'u şikayetinin çözüldüğünü, $\% 42,8$ 'i çözülmediğini, $\% 35,3$ ise kısmen çözüldüğünü belirtmişlerdir. 
Tablo 3

Ölçeklere Ait Faktörlerin Güvenilirlik ve Geçerlilik Analizi Sonuçları

\begin{tabular}{|c|c|c|c|c|c|c|}
\hline Faktörler & $\begin{array}{c}\text { Faktör } \\
\text { Yükü }\end{array}$ & VIF & Cronbach Alfa & rho_A & AVE & CR \\
\hline Dakiklik & & & \multirow{5}{*}{0.941} & \multirow{5}{*}{0.941} & \multirow{5}{*}{0.800} & \multirow{5}{*}{0.941} \\
\hline Dk1 & 893 & 3.666 & & & & \\
\hline Dk2 & ,915 & 4.417 & & & & \\
\hline Dk3 & 879 & 4.044 & & & & \\
\hline Dk4 & 892 & 3.801 & & & & \\
\hline \multicolumn{3}{|l|}{ Kolaylaştırma } & \multirow{5}{*}{0.918} & \multirow{5}{*}{0.922} & \multirow{5}{*}{0.740} & \multirow{5}{*}{0.919} \\
\hline K11 & ,791 & 2.570 & & & & \\
\hline $\mathrm{K} 12$ & ,920 & 4.179 & & & & \\
\hline $\mathrm{K} 13$ & 876 & 3.956 & & & & \\
\hline K14 & 848 & 2.536 & & & & \\
\hline \multicolumn{3}{|l|}{ Nezaket } & \multirow{5}{*}{0.942} & \multirow{5}{*}{0.943} & \multirow{5}{*}{0.803} & \multirow{5}{*}{0.942} \\
\hline Nz1 & 842 & 4.890 & & & & \\
\hline $\mathrm{Nz2}$ & ,920 & 5.557 & & & & \\
\hline $\mathrm{Nz3}$ & 908 & 4.655 & & & & \\
\hline $\mathrm{Nz} 4$ & 911 & 2.871 & & & & \\
\hline \multicolumn{3}{|l|}{ Özür } & \multirow{5}{*}{0.938} & \multirow{5}{*}{0.938} & \multirow{5}{*}{0.790} & \multirow{5}{*}{0.938} \\
\hline Oz1 & ,902 & 3.839 & & & & \\
\hline Oz2 & 851 & 4.695 & & & & \\
\hline $\mathrm{Oz3}$ & 884 & 4.392 & & & & \\
\hline $\mathrm{Oz} 4$ & ,918 & 3.443 & & & & \\
\hline \multicolumn{3}{|l|}{ Telafi } & \multirow{5}{*}{0.937} & \multirow{5}{*}{0.939} & \multirow{5}{*}{0.833} & \multirow{5}{*}{0.937} \\
\hline T11 & 850 & 3.368 & & & & \\
\hline $\mathrm{T} 12$ & 920 & 5.106 & & & & \\
\hline $\mathrm{Tl} 3$ & 920 & 4.677 & & & & \\
\hline T14 &,- 318 & & & & & \\
\hline \multicolumn{3}{|c|}{ Olumlu Ağızdan Ağıza İletişim } & \multirow{7}{*}{0.961} & & & \\
\hline Oa1 & ,915 & 4.208 & & & & \\
\hline $\mathrm{Oa} 2$ & ,932 & 5.345 & & & & \\
\hline Oa3 & 927 & 5.208 & & 0.963 & 0.804 & 0.961 \\
\hline $\mathrm{Oa} 4$ & ,916 & 5.516 & & & & \\
\hline Oa5 & 801 & 3.369 & & & & \\
\hline Oa6 & 883 & 4.654 & & & & \\
\hline Tekrar Satın Alma Niy & & & & & & \\
\hline Ts1 & 870 & 3.641 & & & & \\
\hline Ts2 & 898 & 6.845 & & & & \\
\hline Ts3 & 895 & 5.982 & 0.948 & 0.954 & 0.762 & 0.950 \\
\hline Ts4 & ,912 & 5.204 & & & & \\
\hline Ts5 & 710 & 1.805 & & & & \\
\hline Ts6 & ,932 & 4.919 & & & & \\
\hline
\end{tabular}

Çalışmanın güvenirliği için Cronbach Alfa ve birleşik güvenirlik (CR) katsayıları incelendiğinde hizmet telafi stratejileri faktörlerinden dakiklik, kolaylaştırma, nezaket, özür ve telafi faktörlerinin ve olumlu ağızdan ağıza iletişim ile tekrar satın alma niyeti ölçeklerinin Cronbach Alfa değerlerinin 0,900 'den yüksek olduğu tespit edilmiştir. Buna dayanarak hizmet telafi stratejileri boyutlarının yüksek güvenilirlik değerleri arasında olduğu söylenebilir. Olumlu ağızdan ağıza iletişim ve tekrar satın alma ölçeklerinin de benzer şekilde 0,900 'den yüksek olduğu belirlenmiştir. Ölçekler yüksek güvenilirlik aralığındadır (Kalayc1, 2010, s. 321). Buna göre faktör ve ölçek uyumlarının geçerliliğinin sağlandığ söylenebilir.

Varyans enflasyon faktörü (VIF) genellikle biçimlendirici göstergelerin doğrusallığını değerlendirmek için kullanılır. 5 veya üzeri VIF değerleri, biçimlendirici olarak ölçülen yapıların göstergeleri arasında kritik doğrusallık 
sorunlarını gösterir. Bununla birlikte, 3 'ten daha düşük VIF değerlerinde de doğrusallık sorunları ortaya çıkabilir (Mason ve Perreault, 1991). İdeal olarak, VIF değerleri 3'e yakın ve daha düşük olmalıdır (Hair ve diğerleri, 2019, s. 11). Bir diğer kaynakta ise VIF değerinin 10'a eşit veya daha büyük olduğu durumlarda ise, çoklu doğrusal bağıntı problemi olduğundan bahsedilmektedir (Albayrak, 2005; Büyükuysal ve Öz, 2016, s. 111). Mevcut çalışmada Nz2, T12, Oa2, Oa3, Oa4, , Ts2, Ts3, Ts4 ifadelerinde VIF değerlerinin 5'in üzerinde olduğu sonucuna ulaşılmıştır. Geri kalan değerlerde ise VIF değerlerinin ortalama değerler içerisinde olduğu tespit edilmiştir.

$\mathrm{R}^{2}$ değeri bağımsız değişkenlerin modelde yer alan bağımlı değişkenleri ne kadar açıkladığını göstermektedir. Araştırmada kullanılan modelde yer alan model değerleri incelendiğinde olumlu ağızdan ağıza iletişimin $\% 67,4^{\prime}$ sinin ve tekrar satın alma niyetinin $\% 70,8^{\prime}$ inin hizmet telafi stratejileri boyutları tarafından açılandığı tespit edilmiştir.
Ölçeğin ayrışma geçerliliğine için ise Fornell ve Larcker (1981) tarafından önerilen FornellLarcker kriter katsayıları hesaplanmıştır. Değerler Tablo 4'de ki gibidir:

Ayrışma geçerliliğinin tespitinde, Fornell ve Larcker (1981, s. 382) tarafından önerilen kriter ile Henseler ve diğerleri (2015) tarafından önerilen HTMT kriterleri kullanılmıştır. Fornell ve Larcker (1981) kriterine göre, araştırmada yer alan yapıların AVE değerlerinin karekökü, araştırmada yer alan yapılar arasındaki korelasyonlardan yüksek olmalıdır (Akt. Köse ve Ayhün, 2021, s. 2075). Tablo 4'de sunulan Fornell Larcker değerleri incelendiğinde, güvenilirlik faktörü hariç her bir faktörün açıklanan ortalama varyans (AVE) değerlerinin kareköklerinin diğer faktörlerin korelasyon değerlerinden yüksek olduğu için ayrışma geçerliliğinin sağlandığı söylenebilir. Hizmet telafi stratejisi alt boyutlarından güvenilirlik boyutu ayrışma geçerliliğini sağlamadığı için ölçekten çıarılmasına karar verilmiştir.

Tablo 4

Fornell- Larcker Criterion (Diskriminant Geçerliliği)

\begin{tabular}{|c|c|c|c|c|c|c|c|}
\hline & KL & DK & $\mathrm{OZ}$ & $\mathrm{NZ}$ & TL & OA & TS \\
\hline KL & 860 & & & & & & \\
\hline DK & 775 & 895 & & & & & \\
\hline $\mathrm{OZ}$ & 791 & ,832 & ,725 & & & & \\
\hline NZ & ,770 & 794 & ,842 & ,896 & & & \\
\hline TL & 761 & 808 & 837 & 895 & ,913 & & \\
\hline OA & 679 & ,735 & ,725 & ,742 & ,807 & 897 & \\
\hline TS & 691 & 792 & ,758 & ,769 & 803 & 870 & ,873 \\
\hline
\end{tabular}

İki değişken arasında Pearson Korelasyon katsayısı(r) 0,00-0,25 ise "çok zayıf ilişki", 0,260,49 ise "zayıf ilişki", 0,50-0,69 ise "orta ilişki", 0,70-0,89 ise "yüksek ilişki", 0,90-1,00 ise "çok yüksek ilişki" olarak kabul edilmektedir (Kalayc1 2010, s. 116). Tablo 4'te verilen korelasyon katsayıları incelendiğinde; kolaylaştırma ile olumlu ağızdan ağıza iletişim $(, 679)$ ve tekrar satın alma niyeti $(, 691)$ arasında orta düzeyde pozitif bir ilişki; dakiklik ile olumlu ağızdan ağıza iletişim $(, 735)$ ve tekrar satın alma niyeti $(, 792)$ arasında yüksek düzeyde pozitif bir ilişki; özür boyutu ile olumlu ağızdan ağıza iletişim $(, 725)$ ve tekrar satın alma niyeti $(, 870)$ arasında yüksek düzeyde pozitif bir ilişki; nezaket boyutu ile olumlu ağızdan ağıza iletişim $(, 742)$ ve tekrar satın alma niyeti $(, 769)$ arasında yüksek düzeyde pozitif bir ilişki; telafi boyutu ile olumlu ağızdan ağıza iletişim $(, 807)$ ve tekrar satın alma niyeti $(, 803)$ arasında yüksek düzeyde pozitif bir ilişki olduğu tespit edilmiştir.

Tablo 5 'te ise Hetorait- Metorait (HTMT) ayrışma geçerliliği sonuçları verilmiştir. Tablo 5'te Hetotrait-Monotrait (HTMT) değerleri incelenmiştir. Henseler ve diğerleri (2015)'nin kriterine göre HTMT araştırmada yer alan tüm değişkenlere ait ifadelerin korelasyonlarının ortalamasının aynı değişkene ait ifadelerin korelasyonlarının geometrik ortalamalara oranlarını ifade etmektedir. 
Tablo 5

Hetotrait- Monotrait (HTMT) Ayrı̧̧ma

Geçerliliğgi

\begin{tabular}{cccccccc}
\hline & KL & DK & OZ & NZ & TL & OA & TS \\
\hline KL & & & & & & & \\
\hline DK &, 776 & & & & & & \\
\hline OZ &, 791 &, 832 & & & & & \\
\hline NZ &, 771 &, 794 &, 843 & & & & \\
\hline TL &, 763 &, 809 &, 838 &, 896 & & & \\
\hline OA &, 678 &, 735 &, 723 &, 741 &, 806 & & \\
\hline TS &, 692 &, 795 &, 759 &, 772 &, 805 &, 872 & \\
\hline
\end{tabular}

Araștırmacılar HTMT değerinin; içerik olarak yakın kavramlarda 0,90'nın, içerik olarak birbirine uzak kavramlarda ise $0,85^{\prime}$ in altında olmasını gerektiğini belirtmişlerdir (Akt. Köse ve Ayhün, 2021, s. 2076). HTMT katsayıları incelendiğinde çoğunlukla değerlerin 0,90 Tablo 6

Model Uyum İndeksi

\begin{tabular}{ccccc}
\hline İndeks & Mükemmel Uyum & İyi Uyum & $\begin{array}{c}\text { Araştırma } \\
\text { Bulgusu }\end{array}$ & Sonuç \\
\hline NFI & $0,95 \leq \mathrm{NFI} \leq 1,00$ & $0,90 \leq \mathrm{NFI} \leq 0,95$ & 0,904 & Iyi Uyum \\
\hline SRMR & $0,00 \leq$ SRMR $\leq 0,05$ & $0,05 \leq \mathrm{SRMR} \leq 0,08$ & 0,029 & Mükemmel Uyum \\
\hline
\end{tabular}

Kaynak: Schumacker ve Lomax, 1996: Akt. Eren ve Önder 2020, s. 216

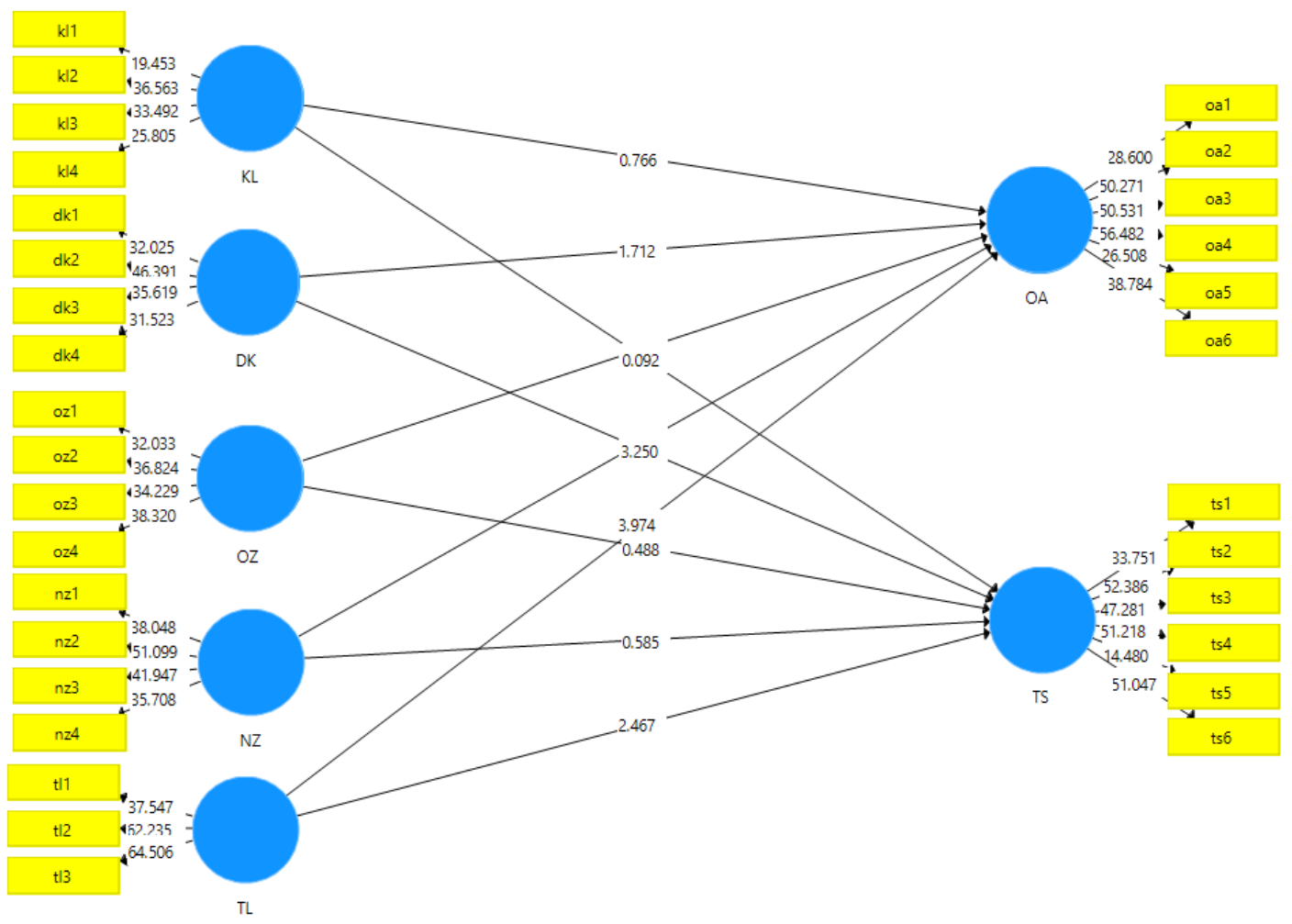

Şekil 2. Yol Katsayılarının Anlamlılık Değerleri

Her bir faktörün yolları arasındaki anlamlılık kullanılmaktadır. Bu değer 1.96'dan büyük ise değerleri ölçümü için $\mathrm{T}$ istatistik değerleri faktör için anlamlı olduğu söylenebilir (Çakır, değerinden düşük olduğu sonucuna ulaşılmiştır. Fornell-Larcker ve HTMT boyutu hariç diğer faktörlerin yapısal eşitlik modellemesi analizine uygun olduğu belirlenmiştir.

\subsection{Yol Analizine İlişkin Sonuçlar}

PLS-SEM yönteminde öncelikle modelin NFI ve SRMR uyum indeksi değerlerine bakılmıştır. Tablo 6 incelendiğinde, model analizine ilişkin uyum indeksleri $\mathrm{NFI}=, 904$ ve SRMR $=029$ olarak belirlenmiştir. Veri sonuçlarına göre modelin iyi uyum gösterdiği söylenebilir. Şekil 2'de consistent bootstrap yöntemi kullanılarak yol analizi yapılmıştır. sonuçlarına göre araştırmada güvenilirlik 
2019, s. 118). Hizmet telafi stratejilerinin dakiklik boyutundan tekrar satın alma niyetine giden yol (KL->TS) arasındaki $\mathrm{T}$ değerinin 3,28 olduğu görülmektedir. Benzer şekilde hizmet telafi stratejilerinin telafi boyutundan olumlu ağızdan ağıza iletişime giden yol (TL-> OA) arasındaki T değerinin 3,99, tekrar satın alma niyetine giden yol (TL->TS) arasındaki T değerinin 2,48 olduğu görülmektedir ve istatiksel olarak anlamlı olduğu tespit edilmiştir. Dolayısıyla $\mathrm{H}_{2 a}$, $\mathrm{H}_{1 e}$ ve

Tablo 7

Yol Katsayıları Anlamlılık Değerleri

\begin{tabular}{lccccc}
\hline & $\begin{array}{c}\text { Orijinal Örneklem } \\
(\mathbf{O})\end{array}$ & $\begin{array}{c}\text { Örneklem } \\
\text { Ortalamasi (M) }\end{array}$ & $\begin{array}{c}\text { Standart Sapma } \\
\text { (STDEV) }\end{array}$ & $\begin{array}{c}\text { T İstatistikleri } \\
\text { (O/STDEV) }\end{array}$ & p \\
\hline KL $>$ OA & 0.196 & 0.196 & 0.116 & 1.690 & 0.091 \\
\hline KL $>$ TS & 0.359 & 0.356 & 0.109 & 3.282 & $\mathbf{0 . 0 0 1}$ \\
\hline DK > OA & 0.073 & 0.069 & 0.095 & 0.776 & 0.438 \\
\hline DK > TS & 0.009 & 0.005 & 0.096 & 0.093 & 0.926 \\
\hline $\mathbf{O Z ~}>$ OA & -0.018 & -0.005 & 0.158 & 0.113 & 0.910 \\
\hline $\mathbf{O Z ~}>$ TS & 0.088 & 0.102 & 0.152 & 0.576 & 0.565 \\
\hline $\mathbf{N Z ~}>$ OA & 0.029 & 0.026 & 0.138 & 0.213 & 0.832 \\
\hline $\mathbf{N Z ~}>$ TS & 0.068 & 0.062 & 0.141 & 0.484 & 0.629 \\
\hline TL $>$ OA & 0.584 & 0.581 & 0.146 & 3.999 & $\mathbf{0 . 0 0 0}$ \\
\hline TL $>$ TS & 0.371 & 0.370 & 0.150 & 2.482 & $\mathbf{0 . 0 1 3}$ \\
\hline
\end{tabular}

\section{Sonuç ve Öneriler}

Sağlık turizmi hizmeti veren işletmelerin amacı, insanlara sunulacak hizmeti uygun ve kaliteli bir şekilde yerine getirmek ve sağlık hizmetlerine karşı talep oluşturmaktır. Sağlık turizmi hizmeti veren işletmelerin başarısı hizmet kalitesine ve müşteri memnuniyetine bağlıdır. Bu yüzden işletmeler tarafından insanların şikâyetlerinin dikkate alınarak çözüme kavuşturulması, kişilerin bu işletmeler hakkında olumlu konuşmasını ve tekrar satın alma niyetlerinin oluşmasını sağlayacaktır. $\mathrm{Bu}$ bağlamda bu çalışma sağlık turizmi hizmeti veren işletmelerde hizmet telafi stratejilerinin olumlu ağızdan ağıza iletişim ve tekrar satın alma niyetine etkisinin incelenmesi amaciyla yapılmıştır. Araştırma kapsamında yapılan analizler sonucunda elde edilen bulgular şu şekildedir:

Model İlk olarak PLS-SEM ile Doğrulayıcı Faktör Analizine tabi tutularak ölçeğin uyum değerlerine, ayrışma geçerliliğine ve iç tutarlılığına bakılmıştır. Buna göre hizmet
$\mathrm{H}_{2 \mathrm{e}}$ hipotezleri kabul edilmiştir. $\mathrm{H}_{1 \mathrm{a}}, \mathrm{H}_{1 \mathrm{~b}}, \mathrm{H}_{1 c}$, $\mathrm{H}_{1 \mathrm{~d}}, \mathrm{H}_{2 \mathrm{~b}}, \mathrm{H}_{2 \mathrm{c}}, \mathrm{H}_{2 \mathrm{~d}}$, hipotezleri reddedilmiştir. $\mathrm{Bu}$ değerlerin tablo şeklindeki gösterimi Tablo 7'de sunulmuştur. Tablo $7^{\prime}$ de gösterilen yol katsayılarının anlamlılık değerleri incelendiğinde $\mathrm{T}$ değerinin KL-> TS, TL-> OA ve TL-> TS yollarında istatistiksel olarak anlamlı olduğu belirlenmiştir $(\mathrm{T}>1,96)$. Dolayısıyla $\mathrm{H}_{2 a}$, $\mathrm{H}_{1 e}$ ve $\mathrm{H}_{2}$ hipotezleri kabul edilmiştir. $\mathrm{H}_{1 a}, \mathrm{H}_{1 b}$, $\mathrm{H}_{1 \mathrm{c}}, \mathrm{H}_{1 \mathrm{~d}}, \mathrm{H}_{2 \mathrm{~b}}, \mathrm{H}_{2 c}, \mathrm{H}_{2 \mathrm{~d}}$, hipotezleri reddedilmiştir. telafi stratejileri ölçeğinin telafi boyutu faktör yükü 0,700 değerinden küçük olduğu için çalışmadan çıkarılmıştır. AVE değerleri incelendiğinde hizmet telafi stratejileri ölçeği faktörleri ile olumlu ağıdan ağıza iletişim ve tekrar satın alma niyeti ölçek AVE değerlerinin 0,50'den büyük olduğu gözlemlenmiştir. Cronbach Alfa değerlerine bakıldığında hizmet telafi stratejilerinin tüm boyutları, olumlu ağızdan ağıza iletişim ve tekrar satın alma ölçeklerinin yüksek güvenirliğe sahip olduğu belirlenmiştir. Fornell-Larcker testi içerisinde yer alan korelasyon analizleri incelendiğinde de, hizmet telafi stratejilerinin tüm boyutları ile olumlu ağızdan ağıza iletişim ve tekrar satın alma niyeti arasında anlamlı ve pozitif bir ilişki olduğu tespit edilmiştir.

Hizmet telafi stratejilerinin olumlu ağıdan ağıza iletişim ve tekrar satın alma niyetine etkisinin incelenmesi amaciyla yapilan yol analizi sonuçlarına göre ise; hizmet telafi stratejileri boyutlarından kolaylaştırma boyutunun tekrar satın alma niyeti üzerinde pozitif bir etkisinin olduğu; dakiklik, özür, 
nezaket ve telafi stratejilerinin ise anlamlı bir etkisinin olmadığ1 sonucuna ulaşılmıştır. Dolayısıyla $\mathrm{H}_{1}$ hipotezi kabul edilirken, $\mathrm{H}_{1 a}$, $\mathrm{H}_{1 b}, \mathrm{H}_{1 c}, \mathrm{H}_{1 d}$ hipotezleri reddedilmiştir. $\mathrm{Bu}$ bulgular ile benzerlik ve farklılık gösteren çalışmalar literatürde mevcuttur. Cengiz vd. (2015: 90) tarafından yapılan bir çalışmada, kolaylaştırma stratejileri sayesinde müşteri şikâyetlerinin etkili bir şekilde yönetilerek tekrar satın alma niyetini artırılabileceği ve kişilerin çevresine hastane ile ilgili olumsuz söylemlerde bulunmasının engellenebileceği belirtilmiştir. Mevcut çalışmada elde edilen bulgunun aksine Mete (2021, s. 89) tarafindan sağlık sektöründe yapılan bir çalışmada ise, hizmet telafi stratejilerinden güvenilirlik ve nezaket boyutunun tekrar satın alma niyetini etkilediği tespit edilmiştir.

Mevcut çalışmada hizmet telafi stratejilerinden telafi boyutunun olumlu ağızdan ağıza iletişim ve tekrar satın alma niyeti üzerinde pozitif bir etkisinin olduğu; kolaylaştırma, dakiklik, özür ve nezaket boyutlarının ise anlamlı bir etkisinin olmadığ tespit edilmiştir. Dolayısıyla $\mathrm{H}_{2 a}$ ve $\mathrm{H}_{2 \mathrm{e}}$ hipotezleri kabul edilirken $\mathrm{H}_{2 b}, \mathrm{H}_{2 c}, \mathrm{H}_{2 \mathrm{~d}}$ hipotezleri red edilmiştir. Mevcut çalışmada elde dilen bu bulguyu destekleyen bir çalışma Çanakgöz (2008, s. 135) tarafından yapılmış ve ilgili çalışmada şikâyetlerin telafi edilmesinin olumlu ağızdan ağıza iletişimi etkilediği sonucuna ulaşılmıştır. Mevcut çalışmada elde edilen bulgunun tersine Cengiz vd. (2015, s. 90) yaptıkları bir çalışmada, hizmet telafi stratejilerinden dakiklik boyutunun tekrar satın almayı etkilediğini tespit etmişlerdir.

Ayrıca çalışmada, katılımcıların en fazla şikâyette bulunduğu sağlık turizmi işletmesi termal turizm işletmeleri iken en fazla şikâyet edilen konu fiyat-reklam-kampanya, ikinci sırada ise personelden kaynaklı şikâyetlerdir. Araştırmaya katılan kişiler en çok kendisi için şikayette bulunurken, şikayetlerini ilk olarak yüz yüze görüşme, sonrasında ise telefon/çağrı merkezi yoluyla ilgili kurumlara iletmektedirler. Son olarak şikâyette bulunan kişilerin çoğunluğu şikayetlerinin çözülmediğini belirtmişlerdir. Elde edilen bulgular doğrultusunda sağlık turizmi hizmet veren işletmelere şu önerilerde bulunabilir:

- Sağlık turizmi hizmeti alan kişilere şikâyetlerini daha kolay iletebilme imkânı yaratılmalıdir.

- Şikâyetlerin daha kolay ve ikna edici şekilde çözüme ulaştırılması gerekmektedir.

- Sağllk turizmi işletmesine şikâyetlerini ileten bireylere daha hızlı bir şekilde yanıt verilmesi hizmetlerin telafisi açısından önemlidir. Çünkü daha hızlı yanıt alınması bireylerin işletmeden memnun kalmasına ve bunun sonucunda işletmeyi tekrar tercih etmesine neden olabilir.

- Hizmet hatalariyla ilgili yapilan şikayetlerde işletmenin ortaya çıkan hatalar için samimi bir şekilde özür dilemesi ve özrün yanında hatanın telafisi için ek hizmet ve promosyon imkanları sağlaması işletme açısından yararlı olabilir.

- Sağlık turizmi hizmeti veren işletmeden kaynaklı hataların şikâyetleriyle ilgili geri bildirim sağlandığında müşterilerin görüşlerine saygı duyulmalı ve hataların telafisi beklenilen seviyede ve nezaketli bir biçimde telafi edilmelidir.

Çalışmada zaman, maliyet ve Covid-19 salgını gibi kısıtlardan dolayı örneklemi oluşturan kişilere ulaşmakta güçlük çekilmiş ve çalışma küçük bir örneklem çerçevesinde gerçekleştirilmiştir. Aynı zamanda Covid-19 salgını nedeniyle sağlık turizm işletmelerinin hizmetlerinde kesintiler meydana gelmiş ve işletmeler tam kapasiteyle hizmet veremediği gibi insanlar salgin döneminde zorunlu olmayan ihtiyaçlarını ertelemişlerdir. Bu kısıtlara rağmen hizmet telafi stratejilerini sağlık turizmi hizmeti veren işletmeler temelinde değerlendiren bir çalışmaya literatürde rastlanılamamış olması ve bu stratejilerin hem olumlu ağızdan ağıza iletişime hem de tekrar satın alma niyetine etkisinin birlikte ele almasindan dolayı çalışmanın literatüre katkıda bulunulacağı düşünülmektedir. Ayrıca çalışmanın sonuçları sağlık turizmi hizmeti alıp şikâyette bulunan 
bireylerin görüşlerini içermesi ve sağlık turizmi hizmeti veren tüm işletmelerin şikâyetlerini kapsaması açısından önemlidir. Gelecekte yapılacak çalışmalarda sağlık turizmi işletmeleri ayrı ayrı ele alınarak, her birinde uygulanan hizmet telafi strateji ve sonuçları incelenebilir.

\section{Araştırma ve Yayın Etiği Beyanı}

$\mathrm{Bu}$ araştırma da kullanılan ölçekler Sivas Cumhuriyet Üniversitesi Bilimsel Araştırma ve Yayın Etiği Kurulu tarafından verilen 04/12/2020 tarih ve 60263016-050.06.04-E.48120 sayılı onay dikkate alınarak uygulanmıştır.

\section{Yazarların Makaleye Katkı Oranları}

Cansel BAŞ, araştırmanın verilerinin toplanması ve analizlerin yapılması kısımlarını gerçekleştirmiştir. Doç. Dr. Şükran KARACA, araştırmanın tasarımını gerçekleştirmiştir. Teorik çerçeve yazarlar tarafından ortak yazılmıştır.

\section{8. Çıkar Beyanı}

$\mathrm{Bu}$ çalışma herhangi bir çıkar çatışmasına konu değildir.

\section{Kaynakça}

Akdu, U. (2019). Otel işletmelerinde uygulanan hizmet hatası telafi stratejilerinin hizmet kalitesi algisına etkisi. Afyon Kocatepe Üniversitesi Sosyal Bilimler Dergisi, 21(2), 625-646.

Aydın, S. (2005). Türk GSM sektöründe müşteri sadakatinin belirleyicileri ve değiştirme maliyeti arasındaki ilişkilerin analizi (Yayınlanmamış Doktora Tezi). Gebze Yüksek Teknoloji Enstitüsü. Kocaeli.

Berman, B. (2005). How to delight your customers. California Management Review, 48(1),129-151.

Bozkaya, T. (2012). Bankacıllk sektöründe hizmet hatası ve hizmet telafisi (Yüksek Lisans Tezi). Balıkesir Üniversitesi. Balıkesir.

Büyükuysal, M. Ç. ve Öz, İ. İ. (2016). Çoklu doğrusal bağıntı varlığında en küçük karelere alternatif yaklaşım: ridge regresyon. Düzce Üniversitesi Sağlık Bilimleri Enstitüsü Dergisi, 6(2), 110-114.

Brown, S. W., Cowles, D. L. ve Tuten, T. L. (1996). Service recovery: 1ts value and limitations as a retail strategy. International Journal of Service Industry Management, 7(5), 32-46.

Cengiz, E., Akdu, S. ve Bostan, M. K. (2015). Sağllk hizmetlerinde hizmet hatası telafi stratejileri. Gümüşhane Üniversitesi Sosyal Bilimler Elektronik Dergisi, 12, 87-101.
Chen, Z. ve Berger, J. (2016). How content acquisition method affects word of mouth. Journal of Consumer Research, 43(1), 86-102.

Conlon, D. E. ve Murray, N. M. (1996). Customer perceptions of corporate responses to product complaints: the role of explanations. Academy of Management Journal, 39(4), 10401056.

Çakırkaya, M. ve Karaboğa, K. (2019). Marka otantizminin tekrar satın alma niyeti üzerindeki etkisi: hazır gıda sektöründe bir uygulama. İşletme Araştırmalar Dergisi, 11(3), 1518-1536.

Çanakgöz, G. (2008). Hizmet telafisinin müşteri memnuniyeti üzerine etkileri: Türk bankacılık sektörü uygulaması (Yayınlanmış Yüksek Lisans Tezi). Ege Üniversitesi, Sosyal Bilimler Enstitüsü, Pazarlama Anabilim Dalı. İzmir.

Çokluk, Ö., Şekercioğlu, G. ve Büyüköztürk, Ş. (2012). Sosyal bilimler için çok değişkenli istatistik: Spss ve lisrel uygulamaları. Pegem Akademi Yayıncilık, Ankara.

Davidow, M. (2003). Organizational responses to customer complaints: what works and what doesn't. Journal of Service Research, 5(3), 225-250.

Davidow, M. (1998). Organizational responses to customer complaints and their impact on post-complaint customer behavior: the mediating effect of perceived justice and satisfaction, Texas A\&M University, Dissertation of Doctor of Philosophy.

Davidow, M. (2000). The bottom line impact of organizational responses to customer complaints. Journal of Hospitality and Tourism Research, 24, 473-490.

Demirel, N. (2019). Müşteri memnuniyetinin ağızdan ağıza iletişim üzerindeki etkisinde hizmet telafisinin düzenleyicilik rolü: Nevşehir'deki otel işletmelerinde bir uygulama (Yayımlanmamış Yüksek Lisans Tezi). Nevşehir Hacı Bektaş Veli Üniversitesi. Nevşehir.

Denizli, F. (2020). Medikal turizm kapsamındaki sağ lık çalışanlarının memnuniyet ve örgütsel bağhllk düzeyleri: kayseri örneği (Yayımlanmamış Yüksek Lisans Tezi). Kayseri Üniversitesi. Kayseri.

Dolinsky, A.L. (1995). Complaint intensity and health care services: a framework to establish priorities for quality improvements can be used to improve patient satisfaction. Journal of Health Care Marketing, 15(2), 42-47

Ferguson, R. J. Paulin, M. ve Leiriao, E. (2006). Loyalty and positive word-of-mouth: patients and hospital personnel as advocates of a customer-centric health care organization. Health Marketing Quarterly, 23(3), 59-77.

Fornell, C. ve Larcker, D. F. (1981). Evaluating structural equation models with unobservable variables and measurement error. Journal of Marketing Research, 18(1), 3950.

Goyette, I., Ricard L., Bergeron J. ve Marticotte F. (2010). EWOM scale: word-of-mouth measurement scale for eservices context. Canadian Journal of Administrative Sciences, 5, 23-27.

Grönroos, C. (1990). Relationship approach to marketing in service contexts: the marketing and organizational behavior interface. Journal of Business Research, 20(1), 3-11. Hair, J. F., Sarstedt, M., Hopkins, L. ve Kuppelwieser, V. G. (2014). Partial least squares structural equation modeling (PLS-SEM). European Business Review, 26(2), 106-121. 
Hayden, A. C. Pichert, J. W. Fawcett, J. Moore, I. N. ve Hickson, G. B. (2010). Best practice for basic an advanced skills in health care service recovery: a case study of a re-admitted patient. The Joint Commission Journal on Quality and Patient Safety, 36(7), 310-318.

Henseler, J., Ringle C. M., Roldán, J. L. ve Cepeda, G. (2015). Proceedings of the 2nd international symposium on partial least squares path modeling. Universiteit Twente.

Kalayc1, Ş. (2010). SPSS uygulamalı çok değişkenli istatistik teknikleri. Ankara: Asil Yayın Dağıtım.

Kılınç, H. (2020). Sağlık turizminde elektronik ağızdan ă̆gza pazarlamanin bölgesel güven ve seyahat niyeti üzerine etkisi: yabancı hastalar üzerine bir araştırma (Yayımlanmamış Yüksek Lisans Tezi). Selçuk Üniversitesi, Sosyal Bilimler Enstitüsü. Konya.

Kim, G.K., Wang, C. ve Mattila, A.S. (2010). The relationship between consumer complaining behavior and service recovery: an integrative review. International Journal of Contemporary Hospitality Management, 7(22), 975- 991.

Köse, B. Ç. ve Ayhün, S. E. (2021). Hizmet kalitesi ve müşteri tatmininin tekrar satın alma niyetine etkisi: z kuşağı kahve dükkânı müşterileri üzerine bir araştırma. Türk Turizm Araştırmaları Dergisi, 5(3), 2067-2085.

Mason, C. H. ve Perreault,, W. D. (1991). Collinearity, power, and interpretation of multiple regression analysis. Journal of marketing research, 28(3), 268-280.

Mete, B. (2021). Sağlık kurumlarında hizmet hatası telafi stratejilerinin müşteri memnuniyeti ve yeniden satı alma niyeti üzerine etkisi (Yüksek Lisans Tezi). Hacettepe Üniversitesi, Sosyal Bilimler Enstitüsü. Ankara.

Michel, S. ve Meuter, M. L. (2008). The service recovery paradox: true but overrated? International Journal of Service Industry Management, 19(4), 441-457.

NQRC (1995). American custorner satisfaction index methodology. Report; University of Michigan Business School.

Özbek, V., Alnıaçık, Ü. ve Koç, F. (2012). Adil olmayan işletme uygulamalarının banka müşterilerinin niyetleri üzerindeki etkisi: deneysel bir çalışma. Ege Akademik Bakış, 12(1), 2330 .
Pişkin, A. ve Ateşoğlu, İ. (2015). Sağllk kurumlarında müşteri memnuniyeti ve değiştirme maliyetlerinin müşteri sadakati üzerindeki etkileri. İşletme Araştırmaları Dergisi, 1-21.

Ratnasari, R. T., Prasetyo, S. A. ve Hendarjatno. (2019). Recommendation and repurchase intention for health service based on medical tourism. KnE Social Sciences, 1030-1043.

Rauyruen, P., Miller, K. E. ve Groth, M. (2009). B2B Services: linking service loyalty and brand equity. Journal of Services Marketing, 23(3), 175-186.

Ridderstaat, J. ve Singh, D. (2020). Increasing health tourism spending in the united states. Rosen Research Review, 2, 38-41.

Tengilimoğlu, D. ve Işık, O. (2013). Sağlık turizmi yönetimi. İstanbul Üniversitesi Açık ve Uzaktan Eğitim Fakültesi.

Türker, G. Ö. (2013). Ağızdan ağıza iletişim ile tüketici odaklı marka değeri arasındaki ilişkinin incelenmesi: tur operatörleri ve seyahat acenteleri müşterileri üzerine bir uygulama. (Yayımlanmamış Doktora Tezi). Turizm İşletmeciliği ve Otelcilik Ana Bilim Dalı, Akdeniz Üniversitesi, Antalya.

Um, Ki-Hyun ve Kim, S.M. (2018). Application of fairness theory to medical tourists' dissatisfaction and complaint behaviors: the moderating role of patient participation in medical tourism. Journal of Social Service Research, 1-18.

Wirtz, J. ve Mattila, A. S. (2003). Consumer responses to compensation, speed of recovery and apology after a service failure. International Journal of Service Industry Management, 15(2), 150-166.

Wongsawat, C. ve Deebhijarn, S. (2020). Factors influencing repurchase intention among foreign medical tourists in bangkok, thailand: a structural equation model. AsiaPacific Social Science Review, 20(1), 109-116.

Yağcl, M. İ. ve Doğrul, Ü. (2015). Hakkaniyet teorisi çerçevesinde tüketicilerin hizmet telafilerini değerlendirme süreci: kavramsal bir inceleme. Çă̆g Üniversitesi Sosyal Bilimler Dergisi, 12(2), 1-22.

Yeoh, E., Othman, K. ve Ahmad, H. (2013). Understanding medical tourists: word-of-mouth and viral marketing as potent marketing tools. Tourism Management, 34, 196201. 